\section{Kerry pledges to axe Yucca Mountain nuclear-waste dump}

Geoff Brumfiel, Washington

Plans for a multimillion-dollar nuclearwaste dump, already shaken by a string of budgetary and legal setbacks, have taken a further knock. The Democrat presidential candidate John Kerry pledged last week to block the scheme if he is elected.

Debate over the Yucca Mountain repository has injected some science into the presidential race, as both candidates campaign heavily for the swing state of Nevada, home to the site. Advocates of nuclear power hope to make Yucca Mountain the nation's primary nuclear dump, but opposition from the state government and scientific questions about the site have delayed the project (see Nature 412, 850-852; 2001).

On 10 August, Kerry used scientific studies to claim the plan was flawed, including one saying that corrosion could destroy the metal waste-storage canisters. "I can sum up my stance on Yucca Mountain in four words," Kerry told supporters in Nevada. "Not on my watch."

His attack was rebuffed by President George W. Bush, who two days later accused Kerry of "trying to turn Yucca Mountain into a political poker chip". Kerry may also be out of step with the scientific evidence. According to a 28 July letter from the Nuclear Waste Technical Review Board, the government agency that raised the corrosion concern, new data show that corrosion is "unlikely".

The campaign rhetoric comes at a turbulent time for the site. The facility is designed to last 10,000 years, but on 10 July a federal appeal court ruled that it must comply with a 1995 National Academy of Sciences study that raises this to 100,000 years. The decision came as federal officials were rushing to file a licence application for the site with the Nuclear Regulatory Commission, which oversees nuclear-waste disposal.

Yucca's advocates are also faced with a budgeting miscalculation that led the House of Representatives in June to approve just $\$ 130$ million of the $\$ \mathbf{8 8 0}$ million requested for the site in the next financial year. Many doubt that the bill, when it is completed, will provide full funding. "The project is caught in a perfect storm right now," says Bob Loux, director of the State of Nevada Agency for Nuclear Projects, which opposes the site.

The fate of the site may now depend on the outcome of the presidential election. If Bush wins, he may be able to negotiate a new 2005 budget for the project.

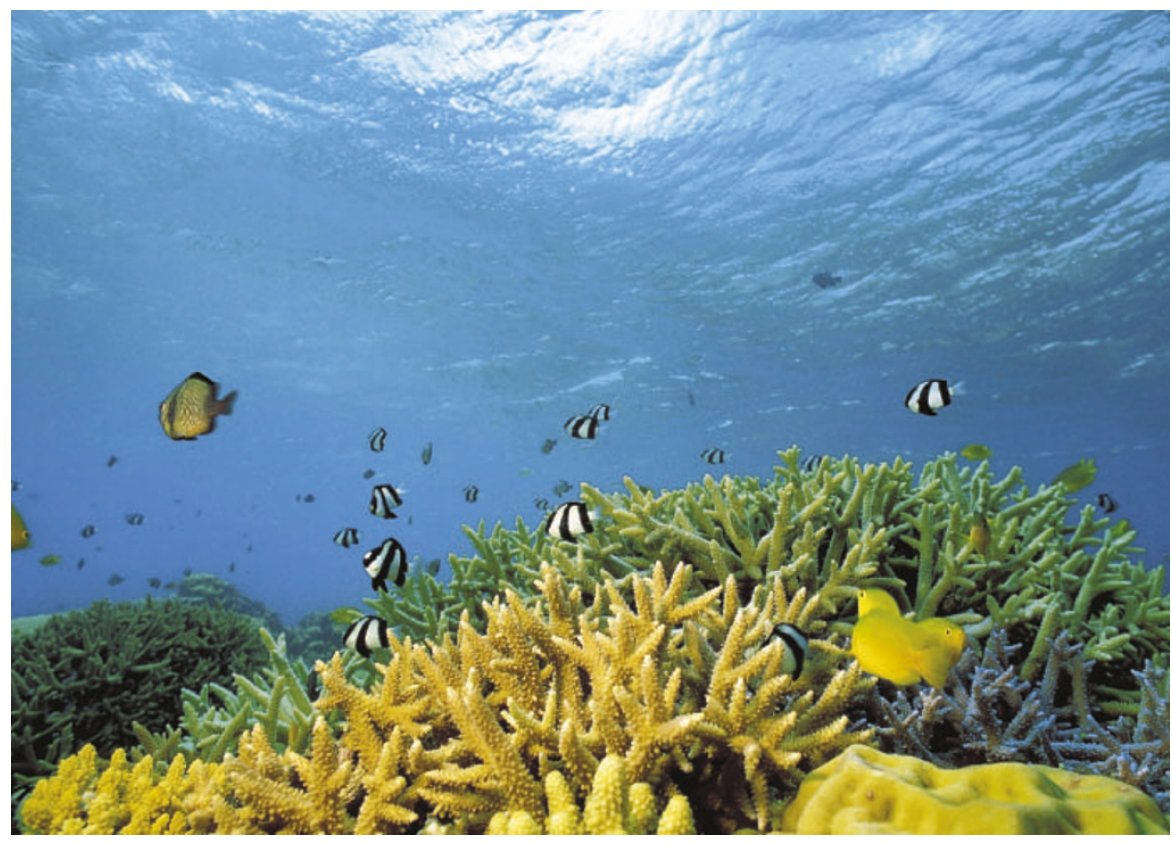

Sea change: falling pH levels caused by carbon dioxide emissions could devastate oceanic ecosystems.

\title{
Researchers seek to turn the tide on problem of acid seas
}

\section{Quirin Schiermeier, Munich}

Researchers met last week to map out plans to study a serious but largely neglected environmental problem — the gradual acidification of the oceans.

Since the industrial revolution, sea surface $\mathrm{pH}$ levels have dropped by around 0.1 units as the oceans absorb atmospheric carbon dioxide. This is already enough to trouble some marine species, but researchers warn that values could fall by a further 0.5 units by 2100 . If steps are not taken to cut $\mathrm{CO}_{2}$ emissions, $\mathrm{pH}$ could drop even further, perhaps to levels that are thought to have triggered catastrophic extinction events in Earth's history (Nature 425, 365; 2003).

"We're taking a huge risk," says Ulf Riebesell, a marine biologist at the Leibniz Institute of Marine Sciences in Kiel, Germany. "Chemical ocean conditions 100 years from now will probably have no equivalent in the geological past, and key organisms may have no mechanisms to adapt to the change."

Aspects of the threat are already being studied, but marine scientists met at the Plymouth Marine Laboratory, UK, on 11-13 August to start work on a comprehensive research plan. The scheme, to be finalized later this year, will list key scientific questions and provide a blueprint for funding agencies and researchers.

Their efforts were due to be boosted on 17 August by news that Britain's Royal Society is to probe the likely changes to marine ecosystems following a rise in ocean acidity.

Studies of the effects of acidification on marine organisms will play a prominent part in the research plan. Last month, researchers showed that the shells and hard skeletons of plankton and corals will begin to dissolve as the oceans become more acid (R. A. Feely et al. Science 305, 362-366; 2004). The loss of these creatures would have incalculable consequences for the entire marine food chain.

Carol Turley, a senior scientist at the Plymouth lab, says researchers will investigate the growth, reproduction and adaptation capability of marine species ranging from bacteria to vertebrates. Results from these experiments will help to shape protocols for open-ocean studies. With the help of measurement tools such as $\mathrm{pH}$ sensors attached to profiling floats, researchers will try to track the subtle ecosystem interactions between the sea surface and the sea floor, and between coastal areas and the open ocean.

Modelling the likely changes in ocean chemistry, and determining how they may affect temperature, salinity and nutrient availability, will be another priority, says Turley. Researchers will also add $\mathrm{CO}_{2}$ to the ocean to simulate long-term changes. Together, these studies should show how biogeochemistry, species diversity and evolution will change in an acidic ocean.

Riebesell hopes that the initiatives, which will be overseen by the Integrated Marine Biogeochemistry and Ecosystem Research project, will influence funding agencies. "We know quite a lot about the ocean of the past," he says. "But we owe it to people to tell them more about the ocean of the future." 